\title{
Intraoperative ventilation: incidence and risk factors for receiving large tidal volumes during general anesthesia
}

\author{
Ana Fernandez-Bustamante ${ }^{1 *}$, Cristina L Wood ${ }^{1}$, Zung V $\operatorname{Tran}^{2}$ and Pierre Moine ${ }^{1}$
}

\begin{abstract}
Background: There is a growing concern of the potential injurious role of ventilatory over-distention in patients without lung injury. No formal guidelines exist for intraoperative ventilation settings, but the use of tidal volumes $\left(\mathrm{V}_{T}\right)$ under $10 \mathrm{~mL} / \mathrm{kg}$ predicted body weight (PBW) has been recommended in healthy patients. We explored the incidence and risk factors for receiving large tidal volumes $\left(V_{T}>10 \mathrm{~mL} / \mathrm{kg}\right.$ PBW).

Methods: We performed a cross-sectional analysis of our prospectively collected perioperative electronic database for current intraoperative ventilation practices and risk factors for receiving large tidal volumes $\left(V_{T}>10 \mathrm{~mL} / \mathrm{kg}\right.$ PBW). We included all adults undergoing prolonged ( $\geq 4 \mathrm{~h}$ ) elective abdominal surgery and collected demographic, preoperative (comorbidities), intraoperative (i.e. ventilatory settings, fluid administration) and postoperative (outcomes) information. We compared patients receiving exhaled tidal volumes $>10 \mathrm{~mL} / \mathrm{kg}$ PBW with those that received 8-10 or $<8 \mathrm{~mL} / \mathrm{kg}$ PBW with univariate and logistic regression analyses.

Results: Ventilatory settings were non-uniform in the 429 adults included in the analysis. 17.5\% of all patients received $V_{T}>10 \mathrm{~mL} / \mathrm{kg}$ PBW. $34.0 \%$ of all obese patients (body mass index, BMl, $\geq 30$ ), $51 \%$ of all patients with a height $<165 \mathrm{~cm}$, and $34.6 \%$ of all female patients received $V_{T}>10 \mathrm{~mL} / \mathrm{kg} P B W$.

Conclusions: Ventilation with $V_{T}>10 \mathrm{~mL} / \mathrm{kg}$ PBW is still common, although poor correlation with PBW suggests it may be unintentional. $\mathrm{BMI} \geq 30$, female gender and height $<165 \mathrm{~cm}$ may predispose to receive large tidal volumes during general anesthesia. Further awareness of patients' height and PBW is needed to improve intraoperative ventilation practices. The impact on clinical outcome needs confirmation.
\end{abstract}

\section{Background}

The lung can be injured by positive pressure ventilation. Mechanical stretch triggers a proinflammatory response within the first 2 hours in healthy animal models [1-4]. The benefit of lung protective ventilation (LPV) with low tidal volumes $\left(\mathrm{V}_{\mathrm{T}}\right)$, usually $6 \mathrm{~mL} / \mathrm{kg}$ predicted body weight (PBW), has been strongly evidenced for patients with acute lung injury and acute respiratory distress syndrome (ALI/ARDS) [5-8]. LPV strategies, designed to limit end-inspiratory volumes and pressures, were associated with reduced inflammatory markers in bronchoalveolar lavage fluid and blood [6-8] and improved clinical outcomes $[5,7,8]$.

\footnotetext{
* Correspondence: Ana.Fernandez-Bustamante@ucdenver.edu

'Department of Anesthesiology, University of Colorado, USA

Full list of author information is available at the end of the article
}

In patients without evidence of existing lung injury, the significance of ventilator-induced lung injury is controversial [9-17]. Clinical studies favoring a LPV regimen in non-ALI patients suggest a decreased inflammatory or pro-coagulation mediators with LPV strategies compared to conventional ventilation $[12,14]$, and some have found improvement in clinical outcomes after thoracic or esophageal surgery $[11,13,15]$. However, inevitable confounders in these studies such as different PEEP and oxygen fractions, and concerns of potential effects of LPV (i.e. atelectasis, hypercapnia, etc.) have prevented from reaching widespread application. Guidelines for intraoperative ventilation are lacking, and the recommended safety threshold for healthy patients has unofficially been set at $\mathrm{V}_{\mathrm{T}}<10 \mathrm{~mL} / \mathrm{kg} \mathrm{PBW}$ [18-21].

We hypothesized that $\mathrm{V}_{\mathrm{T}}>10 \mathrm{~mL} / \mathrm{kg}$ PBW is still often applied in routine intraoperative ventilatory set up.

\section{C) Biomed Central}


We expected $\mathrm{a}<10 \%$ of patients receiving unintentional large tidal volumes because of reduced height or obesity-related height/weight disproportion. We performed an observational cross-sectional analysis of our perioperative electronic database to study the incidence of and risk factors for receiving intraoperative $\mathrm{V}_{\mathrm{T}}>10$ $\mathrm{mL} / \mathrm{kg}$ PBW during general anesthesia.

\section{Methods}

After IRB exempt approval (COMIRB\#10-0551), all patients $\geq 18$ years old who underwent elective abdominal surgery of $\geq 4 \mathrm{~h}$ at our institution from August 2007 to May 2010 were included in this cross-sectional analysis. A threshold of $4 \mathrm{~h}$ duration was arbitrarily chosen to exclude short abdominal procedures where mechanical ventilation might be too brief and/or unreflective of non-spontaneous ventilatory settings. All data have been collected from clinical documentation entered by anesthesiology residents, attending staffs, and certified registered nurse anesthetists into the institution's perioperative clinical information system (Centricity ${ }^{\circledR}$ General Electric Healthcare, Waukesha, WI). Collected information included patient characteristics (age, gender, height weight, preoperative comorbidities: obesity, defined as a body mass index, BMI, $\geq 30 \mathrm{~kg} / \mathrm{m}^{2}$, asthma, COPD/emphysema, obstructive sleep apnea, oxygen dependency, congestive heart failure, diagnosed cancer), intraoperative management (ventilatory settings, blood gas analysis, administered intravenous fluids, need of blood products or vasopressors), and postoperative course and outcomes (need of postoperative mechanical ventilation (POMV) and ICU admission, duration of mechanical ventilation, ICU and hospital length of stay, in-hospital mortality).

Patients' predicted body weight was calculated by the following formulas [7]: Males: PBW $(\mathrm{kg})=50+0.91 \times$ (height $(\mathrm{cm})-152.4)$; Females: PBW $(\mathrm{kg})=45.5+0.91$ $\times$ (height $(\mathrm{cm})-152.4)$. Exhaled recorded tidal volumes $\left(\mathrm{V}_{\mathrm{T}}\right)$, in $\mathrm{mL}$ per $\mathrm{kg}$ PBW were calculated. Patients with median values of intraoperative exhaled $\mathrm{V}_{\mathrm{T}}$ less than 8 $\mathrm{mL} / \mathrm{kg}$ PBW (< $8 \mathrm{~mL} / \mathrm{kg}$ PBW), 8-10 mL/kg PBW (8-10 $\mathrm{mL} / \mathrm{kg} \mathrm{PBW}$ ) and greater than $10 \mathrm{~mL} / \mathrm{kg} \mathrm{PBW}(>10$ $\mathrm{mL} / \mathrm{kg} \mathrm{PBW}$ ) were a priori selected for comparison. While $\mathrm{V}_{\mathrm{T}} 10 \mathrm{~mL} / \mathrm{kg} \mathrm{PBW}$ is the $\mathrm{V}_{\mathrm{T}}$ limit mostly accepted and recommended as safe in healthy patients, the $\mathrm{V}_{\mathrm{T}}<8 \mathrm{~mL} / \mathrm{kg}$ PBW threshold is an arbitrary limit chosen in this study for the purpose of statistical comparison. Though arbitrary, $\mathrm{V}_{\mathrm{T}}$ values $<8 \mathrm{~mL} / \mathrm{kg} \mathrm{PBW}$ are more similar than $8-10 \mathrm{~mL} / \mathrm{kg} \mathrm{PBW}$ to the resting tidal volumes of spontaneously breathing adults (7-8 $\mathrm{mL} / \mathrm{kg}$ ) and also to those $\mathrm{V}_{\mathrm{T}}$ values shown to be protective in ARDS patients [5,7]. All aforementioned variables (demographics, comorbidities, intraoperative management and outcomes) from the three $\mathrm{V}_{\mathrm{T}}$ subgroups were compared to detect differences that may be implicated in the use of $\mathrm{V}_{\mathrm{T}}>10 \mathrm{~mL} / \mathrm{kg} \mathrm{PBW}$.

\section{Statistical Analysis}

Descriptively, for continuous variables, mean \pm SD are shown, nominal variables are shown as percentages (n, \%) [7]. Median values of ventilatory parameters $\left(V_{T}\right.$, respiratory rate, peak pressure, etc) from each patient were selected, instead of the means, for calculating the subgroups averages to minimize errors of extreme values from spontaneous ventilation or rapid intraoperative adjustments. Variables were compared using either one-way ANOVA or Chi-square to detect potential differences between the different $\mathrm{V}_{\mathrm{T}}$ subgroups: $>10 \mathrm{~mL} /$ $\mathrm{kg}$ PBW, 8-10 mL/kg PBW and $<8 \mathrm{~mL} / \mathrm{kg}$ PBW. Logistic regression analysis was performed including patients from all $\mathrm{V}_{\mathrm{T}}$ subgroups with significant variables from the univariate analysis. All statistical analysis was performed with SPSS 18.0 software. $\mathrm{p}<0.05$ was considered to be statistically significant.

\section{Results}

429 patients met inclusion criteria and their characteristics are summarized in Table 1 . Exhaled $\mathrm{V}_{\mathrm{T}}$ values from all patients averaged $579.0 \pm 99.3 \mathrm{~mL}(8.7 \pm 1.6 \mathrm{~mL} / \mathrm{kg}$ $\mathrm{PBW})$ and ranged from $344.0 \mathrm{~mL}(5.1 \mathrm{~mL} / \mathrm{kg} \mathrm{PBW})$ to $880.0 \mathrm{~mL}$ (15.4 mL/kg PBW). 154 patients (35.9\%) were ventilated with a median exhaled $\mathrm{V}_{\mathrm{T}}<8 \mathrm{~mL} / \mathrm{kg} \mathrm{PBW}$, 200 patients $(46.6 \%)$ with a $\mathrm{V}_{\mathrm{T}} 8-10 \mathrm{~mL} / \mathrm{kg} \mathrm{PBW}$, and 75 patients $(17.5 \%)$ with $\mathrm{V}_{\mathrm{T}}>10 \mathrm{~mL} / \mathrm{kg} \mathrm{PBW}$. Volume Control Ventilation was used in 386 (90.0\%) patients, Pressure Control Ventilation in $4(0.8 \%)$ patients. The ventilatory mode was not recorded in 39 (9.1\%) patients.

Statistically significant differences between $V_{T}$ subgroups were found in several variables (Table 2). When patients from both extreme subgroups were compared, patients in the $\mathrm{V}_{\mathrm{T}}>10 \mathrm{~mL} / \mathrm{kg}$ PBW subgroup showed a significantly greater proportion of females and obese patients (defined as $\mathrm{BMI} \geq 30$ ) than patients receiving $\mathrm{V}_{\mathrm{T}}<8 \mathrm{~mL} / \mathrm{kg}$ PBW. Patients in the $\mathrm{V}_{\mathrm{T}}>10 \mathrm{~mL} / \mathrm{kg}$ PBW had significantly smaller heights and predicted body weights (PBW), although the average weight was similar and consequently the average body mass index (BMI) was significantly greater than those receiving $\mathrm{V}_{\mathrm{T}}$ $<8 \mathrm{~mL} / \mathrm{kg}$ PBW. The larger median exhaled $V_{T}$ was associated with a significantly increased minute volume ventilation, reduced respiratory rates, greater peak pressures and lower values of end-tidal $\mathrm{CO}_{2}$ partial pressure. No differences in PEEP pressure, inspired oxygen fraction or arterial oxygenation were found between $V_{T}$ subgroups. Duration of the surgical procedure and the estimated blood loss were slightly greater in the $V_{T}>10$ $\mathrm{mL} / \mathrm{kg}$ PBW subgroup but did not reach statistical significance. Transfusion of blood products, but not of 
Table 1 Demographic characteristics of patients who underwent prolonged $(\geq 4 \mathrm{~h}$ ) abdominal surgery

\begin{tabular}{|c|c|}
\hline Number & 429 \\
\hline Age (years), Mean $\pm S D$ & $58.1 \pm 14.9$ \\
\hline \multicolumn{2}{|l|}{ Gender distribution } \\
\hline Male, n(\%) & $293(68.3 \%)$ \\
\hline Female, $n(\%)$ & $136(31.7 \%)$ \\
\hline \multicolumn{2}{|l|}{ ASA classification } \\
\hline $1, n(\%)$ & $21(4.9 \%)$ \\
\hline $2, n(\%)$ & 169(39.4\%) \\
\hline $3, \mathrm{n}(\%)$ & $194(45.2 \%)$ \\
\hline $4, n(\%)$ & $13(3.0 \%)$ \\
\hline Unclassified & $32(7.5 \%)$ \\
\hline \multicolumn{2}{|l|}{ Comorbidities } \\
\hline COPD, n(\%) & $30(7.0 \%)$ \\
\hline Asthma, n(\%) & $30(7.0 \%)$ \\
\hline Obstructive Sleep Apnea, n(\%) & $63(14.7 \%)$ \\
\hline Oxygen dependency, n(\%) & $18(4.2 \%)$ \\
\hline Obesity (BMI $\geq 30), \mathrm{n}(\%)$ & $147(34.3 \%)$ \\
\hline Congestive Heart Failure, n(\%) & $14(3.3 \%)$ \\
\hline Cancer, n(\%) & $276(64.3 \%)$ \\
\hline \multicolumn{2}{|l|}{ Surgical diagnosis } \\
\hline Cancer (Gl, GYN or GU origin), n(\%) & $276(64.3 \%)$ \\
\hline GU stricture/fistula repair, n(\%) & $78(18.2 \%)$ \\
\hline Incontinence/Neurogenic bladder, n(\%) & $36(8.4 \%)$ \\
\hline Other, n(\%) & $39(9.1 \%)$ \\
\hline Duration of surgical procedure (minutes), Mean \pm SD & $347.5 \pm 94.6$ \\
\hline \multicolumn{2}{|l|}{ Outcomes } \\
\hline POMV and ICU admission, $\mathrm{n}(\%)$ & $62(14.5 \%)$ \\
\hline POMV duration (days), Mean \pm SD $^{a}$ & $1.8 \pm 3.4$ \\
\hline ICU LOS (days), Mean \pm SD ${ }^{a}$ & $4.1 \pm 5.7$ \\
\hline Hospital LOS (days), Mean \pm SD & $7.0 \pm 6.7$ \\
\hline In-hospital mortality, n(\%) & $6(1.4 \%)$ \\
\hline
\end{tabular}

(ASA = American Society of Anesthesiologists; BMI = Body Mass Index; COPD = Chronic Obstructive Pulmonary Disease; GI = Gastrointestinal; GYN = Gynecological; GU = Genitourinary; POMV = Postoperative mechanical ventilation)

a Only patients that required POMV and ICU stay were included in this calculation

other intravenous fluids, was significantly increased in the large $\mathrm{V}_{\mathrm{T}}$ subgroup.

Logistic regression analysis, including all significant variables from the univariate analysis, found obesity as the most significant risk factor for a patient receiving a $\mathrm{V}_{\mathrm{T}}>10 \mathrm{~mL} / \mathrm{kg}$ PBW (OR 8.7) but did not result in a reliable prediction equation (overall correct classification $85.4 \%$, Nagelkerke $\mathrm{R}^{2}=0.61$ ). The use of blood products was not significant in this analysis.

The relationship between the median exhaled $V_{T}$ (in $\mathrm{mL}$ ) of all patients plotted against their actual body weight and predicted body weight (PBW) showed a poor correlation (correlation coefficients: 0.30 and 0.24 , respectively). The correlation between the $\mathrm{V}_{\mathrm{T}}$ with the
PBW was greater when patients from the $V_{T}$ subgroups were plotted separately (Figures 1a-c). Note that most patients in the $\mathrm{V}_{\mathrm{T}}<8 \mathrm{~mL} / \mathrm{kg} \mathrm{PBW}$ had heights $>165$ $\mathrm{cm}$ and $\mathrm{PBW}>60 \mathrm{~kg}$, while most patients in the $\mathrm{V}_{\mathrm{T}}>$ $10 \mathrm{~mL} / \mathrm{kg}$ PBW had heights $<165 \mathrm{~cm}$ and $\mathrm{PBW}<60 \mathrm{~kg}$ (Figures 1d-f).

$34.0 \%$ of all obese patients and $34.6 \%$ of all females in the 429 patient cohort were ventilated using $\mathrm{V}_{\mathrm{T}}>10$ $\mathrm{mL} / \mathrm{kg}$ PBW. Figure 2 shows the significantly different distribution of gender and obesity in the $\mathrm{V}_{\mathrm{T}}$ subgroups $(\mathrm{p} \leq 0.001)$.

The incidence of postoperative mechanical ventilation (POMV) and ICU admission was greater in patients receiving $\mathrm{V}_{\mathrm{T}}>10 \mathrm{~mL} / \mathrm{kg}$ PBW compared with the $\mathrm{V}_{\mathrm{T}}<$ $8 \mathrm{~mL} / \mathrm{kg}$ PBW subgroup. POMV duration and ICU length of stay were comparable in both groups, but hospital length of stay was more prolonged in the large $V_{T}$ subgroup. The distribution of gender and obesity in patients requiring POMV and ICU admission was significantly different in the $\mathrm{V}_{\mathrm{T}}$ subgroups (Figure 3). Of those 62 patients needing POMV and ICU admission, only 31 required mechanical ventilation for at least $24 \mathrm{~h}$ and had ventilatory data recorded. Pressure ventilatory modes were the only controlled or assisted/controlled modes used (PRVC, PCV, PSV, CPAP). Median tidal volumes in the ICU were significantly smaller than those used intraoperatively $(573.9 \pm 90.4$ vs. $530.8 \pm$ 98.6, $\mathrm{n}=26)(\mathrm{p}=0.040$ by paired t-test). 19 of these 31 patients had oxygenation criteria of ARDS $\left(\mathrm{PaO}_{2} / \mathrm{FiO}_{2}<\right.$ $200)$ and 2 of ALI $\left(\mathrm{PaO}_{2} / \mathrm{FiO}_{2}\right.$ 200-300) (radiographic criteria not available) during their ICU stay: 7 patients had received an intraoperative $\mathrm{V}_{\mathrm{T}}<8 \mathrm{~mL} / \mathrm{kg} \mathrm{PBW}$ (4.5\% of that $\mathrm{V}_{\mathrm{T}}$ subgroup), 9 a $\mathrm{V}_{\mathrm{T}} 8-10 \mathrm{~mL} / \mathrm{kg} \mathrm{PBW}$ (4.5\% of that $\mathrm{V}_{\mathrm{T}}$ subgroup) and 5 a $\mathrm{V}_{\mathrm{T}}>10 \mathrm{~mL} / \mathrm{kg}$ PBW (6.7\% of that $\mathrm{V}_{\mathrm{T}}$ subgroup) $(\mathrm{p}=0.736) .6$ patients died during their hospital postoperative stay. All of them had been admitted to the ICU, but their intraoperative ventilatory settings were not significantly different.

\section{Discussion}

The present study showed that: 1) Intraoperative ventilatory settings are not uniform; 2) intraoperative ventilation with large tidal volumes $\left(\mathrm{V}_{\mathrm{T}}>10 \mathrm{~mL} / \mathrm{kg} \mathrm{PBW}\right)$ may occur in more than $15 \%$ of surgical patients; 3 ) intraoperative tidal volumes do not routinely correlate with accurate predicted body weight calculations; and 4) obesity, female gender or short height are risk factors for receiving large $\mathrm{V}_{\mathrm{T}}$ during prolonged abdominal surgery.

Our study presents obvious limitations: it is a historical analysis that includes a relatively small number of patients from a single institution. Our results, however, suggest that the lack of formal guidelines on 
Table 2 Characteristics of patients according to their intraoperative median exhaled tidal volumes $\left(\mathrm{V}_{\mathrm{T}}\right)(\mathrm{mL} / \mathrm{kg} \mathrm{PBW})$

\begin{tabular}{|c|c|c|c|c|}
\hline & \multicolumn{3}{|c|}{ Median $\mathrm{V}_{\mathrm{T}}$ subgroups $(\mathrm{mL} / \mathrm{kg} \mathrm{PBW})^{\mathrm{a}}$} & \multirow[b]{2}{*}{$p$ value } \\
\hline & $<8$ & 8-10 & $>10$ & \\
\hline Number, n(\%) & $154(29.5 \%)$ & $200(38.3 \%)$ & $75(14.4 \%)$ & \\
\hline Age (years), Mean \pm SD & $59.6 \pm 14.1$ & $57.4 \pm 15.1$ & $56.9 \pm 15.6$ & 0.298 \\
\hline Gender distribution & & & & $\leq 0.001$ \\
\hline Male, $n(\%)$ & $124(80.5 \%)$ & $141(70.5 \%)$ & $28(37.7 \%) *$ & \\
\hline Female, $n(\%)$ & $30(19.5 \%)$ & $59(29.5 \%)$ & $47(62.7 \%) *$ & \\
\hline Height $(\mathrm{cm})$, Mean \pm SD & $177.9 \pm 9.7$ & $173.7 \pm 9.7$ & $161.4 \pm 11.0 *$ & $\leq 0.001$ \\
\hline Weight $(\mathrm{kg})$, Mean \pm SD & $84.1 \pm 20.2$ & $86.3 \pm 21.3$ & $89.6 \pm 25.9$ & 0.207 \\
\hline Predicted Body Weight $(\mathrm{PBW})(\mathrm{kg})$, Mean \pm SD & $72.9 \pm 9.9$ & $68.4 \pm 10.2$ & $55.7 \pm 10.8 *$ & $\leq 0.001$ \\
\hline Body Mass Index (BMI), Mean \pm SD & $26.5 \pm 5.4$ & $28.4 \pm 5.4$ & $34.1 \pm 8.9 *$ & $\leq 0.001$ \\
\hline ASA classification & & & & 0.884 \\
\hline $1, n(\%)$ & $6(3.9 \%)$ & $12(6.0 \%)$ & $3(4.0 \%)$ & \\
\hline $2, n(\%)$ & $61(39.6 \%)$ & $79(39.5 \%)$ & $29(38.7 \%)$ & \\
\hline $3, n(\%)$ & $73(47.4 \%)$ & $86(43.0 \%)$ & $35(46.7 \%)$ & \\
\hline $4, n(\%)$ & $6(3.9 \%)$ & $5(2.5 \%)$ & $2(2.6 \%)$ & \\
\hline Unclassified, n(\%) & $8(5.2 \%)$ & $18(9.0 \%)$ & $6(8.0 \%)$ & \\
\hline \multicolumn{5}{|l|}{ Comorbidities } \\
\hline COPD, n(\%) & $12(7.8 \%)$ & $16(8.0 \%)$ & $2(2.7 \%)$ & 0.270 \\
\hline Asthma, n(\%) & $10(6.5 \%)$ & $14(7.0 \%)$ & $6(8.0 \%)$ & 0.916 \\
\hline Obstructive Sleep Apnea, n(\%) & 18(11.7\%) & $32(16.0 \%)$ & 13(17.3\%) & 0.407 \\
\hline Oxygen dependency, n(\%) & $8(5.2 \%)$ & $7(3.5 \%)$ & $3(4.0 \%)$ & 0.730 \\
\hline Obesity (BMI $\geq 30), \mathrm{n}(\%)$ & $33(22.6 \%)$ & $64(33.2 \%)$ & $50(68.5 \%) *$ & $\leq 0.001$ \\
\hline Congestive Heart Failure, n(\%) & $2(1.3 \%)$ & $11(5.5 \%)$ & $1(1.3 \%)$ & 0.051 \\
\hline Cancer, n(\%) & $106(68.8 \%)$ & $124(62.0 \%)$ & $46(61.3 \%)$ & 0.681 \\
\hline \multicolumn{5}{|l|}{ Intraoperative ventilatory management } \\
\hline Minute ventilation $(\mathrm{L} / \mathrm{min})$, Mean $\pm \mathrm{SD}$ & $75.9 \pm 14.2$ & $88.5 \pm 13.8$ & $108.7 \pm 21.5 *$ & $\leq 0.001$ \\
\hline Respiratory rate (breath/min), Mean \pm SD & $10.6 \pm 1.9$ & $10.0 \pm 1.6$ & $9.6 \pm 1.6 *$ & $\leq 0.001$ \\
\hline Peak pressure $\left(\mathrm{cmH}_{2} \mathrm{O}\right)$, Mean $\pm \mathrm{SD}$ & $20.9 \pm 6.3$ & $22.2 \pm 5.6$ & $23.6 \pm 6.6 *$ & 0.004 \\
\hline PEEP $\left(\mathrm{cmH}_{2} \mathrm{O}\right)$, Mean $\pm \mathrm{SD}$ & $3.7 \pm 1.9$ & $3.8 \pm 2.3$ & $3.9 \pm 1.9$ & 0.819 \\
\hline End-tidal $\mathrm{CO}_{2}(\mathrm{mmHg})$, Mean $\pm \mathrm{SD}$ & $35.4 \pm 4.2$ & $34.3 \pm 2.6$ & $33.9 \pm 2.7 *$ & 0.004 \\
\hline Mean $\mathrm{FiO}_{2}$, Mean $\pm \mathrm{SD}$ & $70.2 \pm 27.2$ & $70.6 \pm 26.6$ & $74.0 \pm 25.2$ & 0.699 \\
\hline $\mathrm{PaO}_{2} / \mathrm{FiO}_{2}$ ratio, Mean $\pm \mathrm{SD}$ & $298.9 \pm 188.2$ & $315.2 \pm 249.4$ & $248.1 \pm 157.5$ & 0.196 \\
\hline Intraoperative use of vasopressors, n(\%) & $25(16.2 \%)$ & $28(14.0 \%)$ & $13(17.3 \%)$ & 0.741 \\
\hline \multicolumn{5}{|l|}{ Intraoperative fluid management } \\
\hline Infused crystalloids $(\mathrm{mL} / \mathrm{kg} / \mathrm{h})$, Mean \pm SD & $7.8 \pm 3.2$ & $8.3 \pm 3.6$ & $8.6 \pm 3.7$ & 0.213 \\
\hline Infused colloids $(\mathrm{mL} / \mathrm{kg} / \mathrm{h})$, Mean \pm SD & $1.8 \pm 1.2$ & $1.8 \pm 1.6$ & $1.4 \pm 0.9$ & 0.656 \\
\hline Estimated blood loss $(\mathrm{mL})$, Mean $\pm \mathrm{SD}$ & $650.6 \pm 661.3$ & $749.6 \pm 802.5$ & $869.1 \pm 887.8$ & 0.127 \\
\hline Fluid balance (evaporation \& insensible losses not included) $(\mathrm{mL} / \mathrm{kg} / \mathrm{h})$, Mean $\pm \mathrm{SD}$ & $6.5 \pm 3.3$ & $7.1 \pm 3.6$ & $7.7 \pm 4.1$ & 0.079 \\
\hline Use of blood products, n(\%) & $27(17.5 \%)$ & $55(27.5 \%)$ & $27(36.0 \%) *$ & 0.007 \\
\hline Duration of surgical procedure (minutes), Mean \pm SD & $340.8 \pm 92.2$ & $345.6 \pm 94.4$ & $366.0 \pm 98.7$ & 0.155 \\
\hline \multicolumn{5}{|l|}{ Outcomes } \\
\hline POMV and ICU admission, $\mathrm{n}(\%)$ & $17(11.0 \%)$ & $27(13.5 \%)$ & $18(24.0 \%) *$ & 0.028 \\
\hline POMV duration (days), Mean $\pm S D^{b}$ & $1.5 \pm 2.8$ & $1.9 \pm 3.8$ & $2.1 \pm 3.7$ & 0.801 \\
\hline ICU LOS (days), Mean \pm SD & $3.3 \pm 3.2$ & $4.8 \pm 6.4$ & $3.7 \pm 6.6$ & 0.488 \\
\hline Hospital LOS (days), Mean \pm SD & $6.2 \pm 6.1$ & $7.0 \pm 6.6$ & $8.3 \pm 7.8 *$ & 0.101 \\
\hline In-hospital mortality, n(\%) & $3(1.9 \%)$ & $2(1.0 \%)$ & $1(1.3 \%)$ & 0.752 \\
\hline
\end{tabular}

(ASA = American Society of Anesthesiologists; $\mathrm{BMI}=$ Body Mass Index; $\mathrm{FiO}_{2}=$ Inspired fraction of oxygen; PaO ${ }_{2}=$ arterial oxygen partial pressure; PEEP = Positive End-Expiratory Pressure; POMV = Postoperative mechanical ventilation)

( $p$ values shown in last column refer to comparison of the three groups, ${ }^{*}$ refers to $p<0.05$ in comparison of extreme groups)

${ }^{a}$ Predicted body weight was calculated by the following formulas [7]: Males: PBW $(\mathrm{kg})=50+0.91 \times($ height $(\mathrm{cm})-152.4)$; Females: PBW $(\mathrm{kg})=45.5+0.91 \times$ (height (cm) - 152.4)

${ }^{b}$ Only patients that required POMV and ICU stay were included in this calculation 

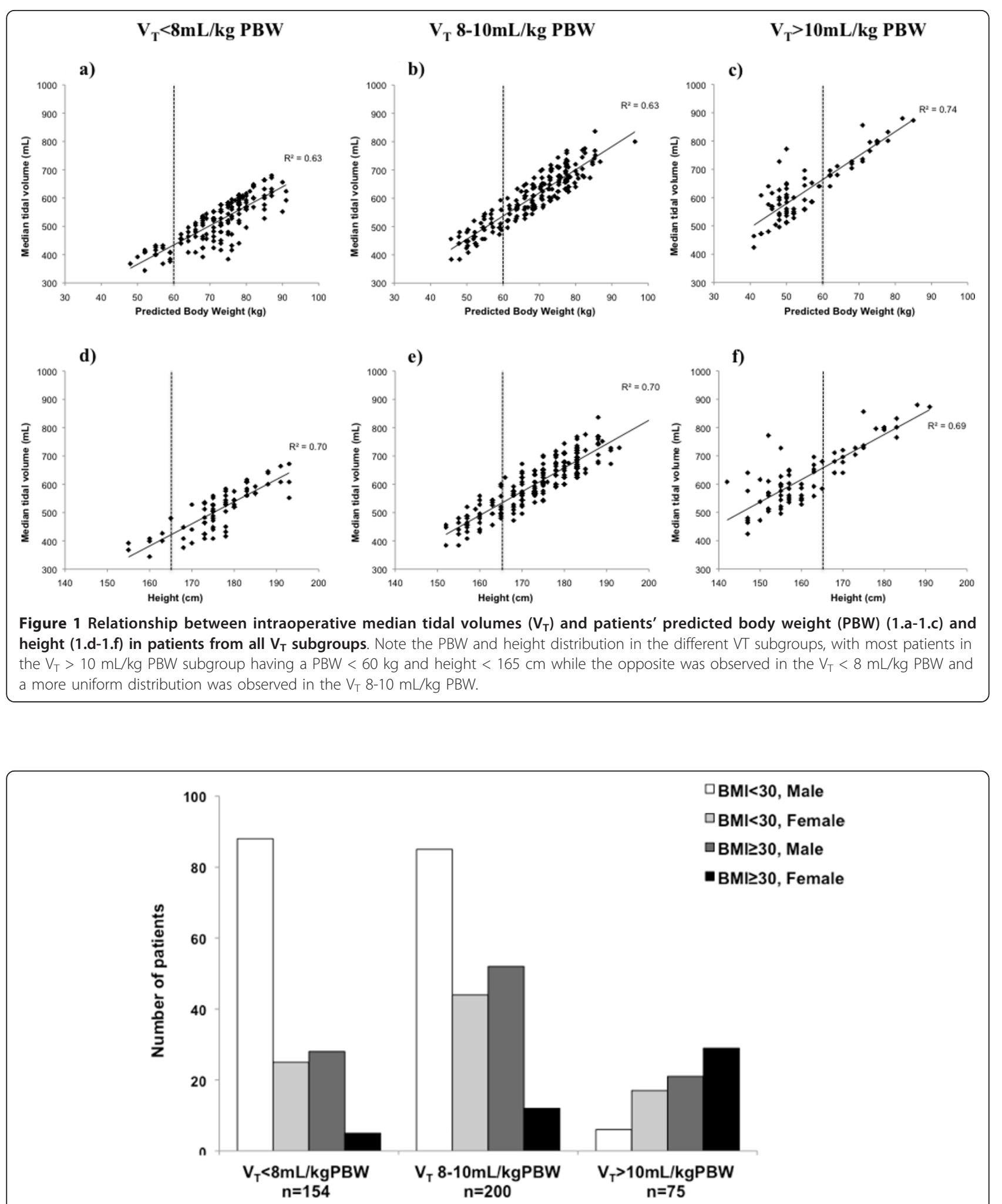

Figure 2 Distribution of obesity and gender on the intraoperative tidal volume $\left(\mathbf{V}_{\mathrm{T}}\right)$ subgroups. The distribution was significantly different between subgroups $(p \leq 0.001)$, with most patients in the $<8 \mathrm{~mL} / \mathrm{kg}$ PBW being non-obese $(73.3 \%)$ and males $(75.3 \%)$ but obese $(66.7 \%)$ and females (61.4\%) in the $>10 \mathrm{~mL} / \mathrm{kg}$ PBW subgroup. There was missing information from 8 patients in the $<8 \mathrm{~mL} / \mathrm{kg}$ PBW subgroup, 7 patients in the $8-10 \mathrm{~mL} / \mathrm{kg}$ PBW subgroup and 2 patients in the $>10 \mathrm{~mL} / \mathrm{kg}$ PBW subgroup (5\%, 3.5\% and 2.7\%, respectively) that precluded their classification. 


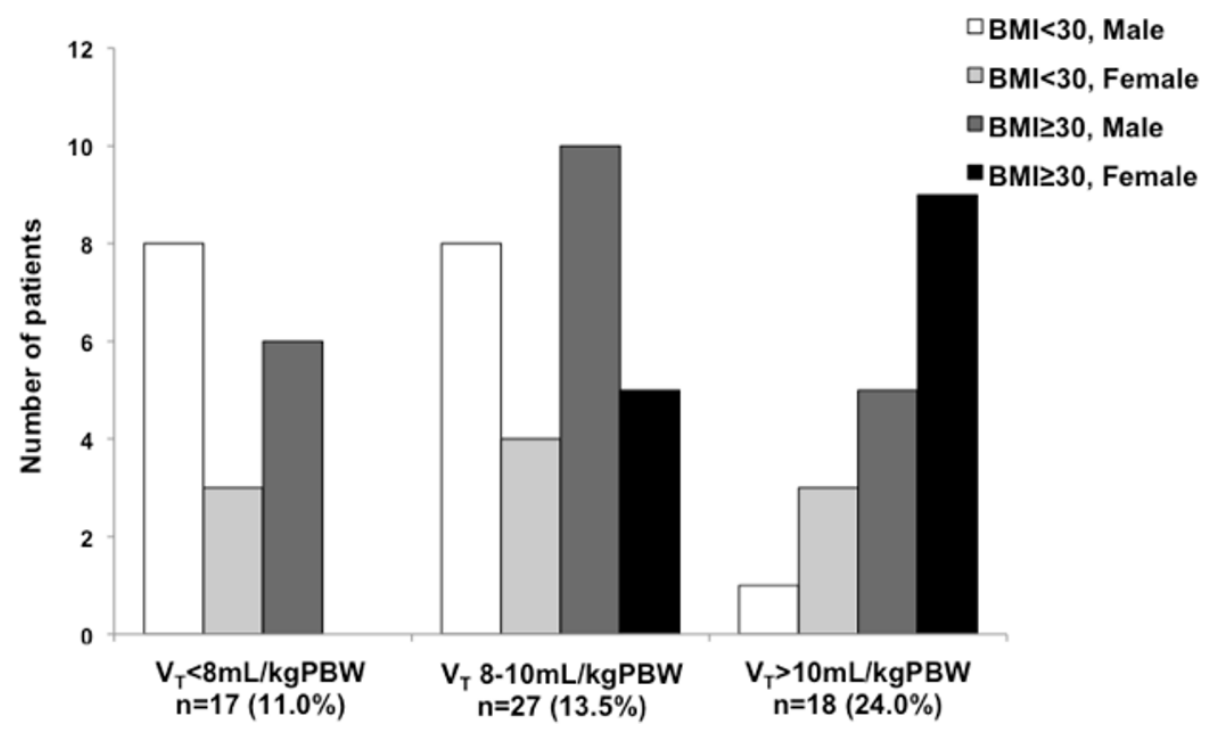

Figure 3 Gender and obesity characteristics of patients that needed postoperative mechanical ventilation (POMV) and ICU admission in tidal volume $\left(\mathbf{V}_{\mathbf{T}}\right)$ subgroups. The incidence of POMV was significantly different in the $\mathrm{V}_{T}$ subgroup $\left(\mathrm{V}_{\boldsymbol{T}}>10 \mathrm{~mL} / \mathrm{kg} \mathrm{PBW} \mathrm{n}=18,24.0 \%\right)$ compared to the other subgroups $\left(n=17,11.0 \%\right.$, in $V_{T}<8 \mathrm{~mL} / \mathrm{kg}$ PBW and $n=29,13.5 \%$, in the $\left.V_{T} 8-10 \mathrm{~mL} / \mathrm{kg} P B W\right)(p=0.028)$. The distribution of gender and obesity of these patients was also significantly different between $V_{T}$ subgroups $(p=0.022)$.

intraoperative ventilation practices is leading to a significant percentage of surgical patients receiving large tidal volumes.

Intraoperative ventilatory settings were not uniform in our study, reflected by the poor correlation between the tidal volumes in the whole patient sample with the predicted body weights or other size variable. The range of observed tidal volumes in $\mathrm{mL} / \mathrm{kg}$ of predicted body weight was wider than expected, especially the highest tidal volume values.

Avoidance of large tidal volumes is, at present, the most efficient strategy to prevent and/or treat acute lung injury (ALI) or acute respiratory distress syndrome (ARDS) $[5,7,22,23]$. In patients without lung injury or risk factors for it, recent reviews recommend the use of $\mathrm{V}_{\mathrm{T}}<10 \mathrm{~mL} / \mathrm{kg}$ PBW $[18,19]$. Other authors have previously observed benefits of a low $\mathrm{V}_{\mathrm{T}}$ ventilation strategy in surgical patients without evidence of lung injury, in terms of decreased inflammation or improved outcomes $[10-15,24]$. In our study, one out of every 6 patients (17.5\% of patients) received intraoperative $\mathrm{V}_{\mathrm{T}}>10 \mathrm{~mL} /$ $\mathrm{kg}$ PBW. This incidence was greater than expected. However, we were not able to find any recent literature presenting the current ventilatory practices during general anesthesia without a predefined intervention or protocol. Furthermore, it is known that compliance with low $\mathrm{V}_{\mathrm{T}}$ ventilation strategies was also difficult to implement even in the ICU setting [25-28], where patients usually present one or more risk factors for ALI/ARDS. Resistance to applying lung protection ventilation strategies has also been observed in patients with ALI criteria during general anesthesia for surgical procedures [29]. So, although potentially a single institution problem, the incidence of $\mathrm{V}_{\mathrm{T}}>10 \mathrm{~mL} / \mathrm{kg}$ PBW may be an underestimated incident that needs to be confirmed and addressed. Measures have been implemented in our institution to minimize these suboptimum practices.

Predicted body weight calculation in adult patients is determined by the patient's gender and height [7]. The correlation between $\mathrm{V}_{\mathrm{T}}$ and the PBW in our patients presented a poor correlation. This correlation greatly improved when the tidal volume subgroups were studied separately, which suggests an important role of the wide range of $\mathrm{V}_{\mathrm{T}}$ used (344.0 to $880.0 \mathrm{~mL}$, corresponding to 5.1 to $15.4 \mathrm{~mL} / \mathrm{kg} \mathrm{PBW}$ ) on the scattering of the whole sample. However, despite a better correlation of $V_{T}$ with the PBW in each $V_{T}$ subgroup, the wide range of $V_{T}$ values still reflects the challenging and often erroneous height-based PBW estimate. Furthermore, PBW and height in the large $\mathrm{V}_{\mathrm{T}}$ subgroup tended to be "shifted to the left" compared to values in the lower $V_{T}$ subgroup (compare Figures $1 \mathrm{a}$ and $1 \mathrm{~d}$ with $1 \mathrm{c}$ and $2 \mathrm{f}$, respectively). This reflects, in our opinion, an inaccurate estimation of the patients' height and therefore PBW in those patients receiving $\mathrm{V}_{\mathrm{T}}>10 \mathrm{~mL} / \mathrm{kg} \mathrm{PBW}$. The PBW formula is not an easy mental calculation, and the lack of effect of weight or BMI is somehow counterintuitive to some providers. These two factors may explain why patients of shorter height and obese patients, with unusual height/weight proportions, are more likely affected by the unintentional use of large tidal volumes. The risk of females and/or short height for receiving large tidal 
volumes has been observed before in the ICU setting [30]. Nonetheless, the surprisingly high incidence in the intraoperative setting of large tidal volumes has, to our knowledge, not been reported. The fact that half of patients with a height $<165 \mathrm{~cm}$, one third of patients with a BMI $\geq 30$ or one third of females may be receiving these large tidal volumes during general anesthesia deserves, in our opinion, further awareness and creative solutions.

The significantly worse clinical outcomes (greater incidence of POMV and ICU admission and longer hospital stay) with the use of $\mathrm{V}_{\mathrm{T}}>10 \mathrm{~mL} / \mathrm{kg}$ PBW compared to the $\mathrm{V}_{\mathrm{T}}<8 \mathrm{~mL} / \mathrm{kg} \mathrm{PBW}$ subgroup are difficult to explain. Known predictors of poor outcome are likely to have been involved in the greater incidence of POMV and ICU admission in the high $\mathrm{V}_{\mathrm{T}}$ subgroup, including obesity and other preoperative comorbidities [31-33] and intraoperative management events (blood transfusion and maybe others) [31,33-35]. The different incidence of blood transfusion within the different $\mathrm{V}_{\mathrm{T}}$ subgroups is difficult to explain, but it may have been more influenced by surgical technical challenge and miscalculation of blood loss/blood volume related to obesity than by a direct link to ventilatory settings. In our study, ICU admission criteria was unclear and not easily available in the electronic database, which may have also contributed to bias from a greater incidence of difficult intubation in obese patients, providers' preferences, time of day, etc. The finding of a greater incidence of pressure assisted ventilatory modes and smaller tidal volumes was not unexpected, and may reflect a greater awareness in ICU providers with the risk of conventional tidal volume ventilation. The impact of intraoperative use of large tidal volumes on the incidence of postoperative ICU admission and ALI/ARDS deserves confirmation from a multicenter study.

\section{Conclusions}

Incidence of intraoperative ventilation with $\mathrm{V}_{\mathrm{T}}>10$ $\mathrm{mL} / \mathrm{kg}$ PBW is probably underestimated because of inaccurate estimates of predicted body weight, especially in obese patients, patients of female gender or with short height. Our findings support the need of a multi-center prospective study to confirm the role of the intraoperative ventilatory insult on clinical outcomes. Meanwhile, it would be helpful to raise awareness among anesthesia providers of the risk of unintentional use of large tidal volumes in obese patients, females or patients with short height. Developing automated tools for accurate predicted body weight calculations in our electronic perioperative medical records or other interventions may help to provide the quality of ventilatory care that is intended in patients during general anesthesia.

\section{Acknowledgements}

The authors thank Ken Bullard for his help with the database analysis and Allen Wentworth for facilitating the ICU database search.

\section{Author details}

'Department of Anesthesiology, University of Colorado, USA. ${ }^{2}$ Department of Biostatistics and Informatics, University of Colorado, USA.

\section{Authors' contributions}

AFB contributed with study design, data collection and analysis, and manuscript drafting. CLW helped with data collection and analysis, and manuscript review. ZVT contributed with data analysis and statistical interpretation and manuscript review. PM helped with study design, data analysis, and manuscript drafting. All authors read and approved the final manuscript.

\section{Competing interests}

The authors declare that they have no competing interests.

Received: 13 June 2011 Accepted: 21 November 2011

Published: 21 November 2011

\section{References}

1. Wolthuis EK, Vlaar AP, Choi G, Roelofs JJ, Juffermans NP, Schultz MJ: Mechanical ventilation using non-injurious ventilation settings causes lung injury in the absence of pre-existing lung injury in healthy mice. Crit Care 2009, 13(1):R1.

2. Copland IB, Kavanagh BP, Engelberts D, McKerlie C, Belik J, Post M: Early changes in lung gene expression due to high tidal volume. Am J Respir Crit Care Med 2003, 168(9):1051-1059.

3. Caruso P, Meireles SI, Reis LF, Mauad T, Martins MA, Deheinzelin D: Low tidal volume ventilation induces proinflammatory and profibrogenic response in lungs of rats. Intensive Care Med 2003, 29(10):1808-1811.

4. Bregeon F, Roch A, Delpierre S, Ghigo E, Autillo-Touati A, Kajikawa O, Martin TR, Pugin J, Portugal H, Auffray JP, et al: Conventional mechanical ventilation of healthy lungs induced pro-inflammatory cytokine gene transcription. Respir Physiol Neurobiol 2002, 132(2):191-203.

5. Amato MB, Barbas CS, Medeiros DM, Magaldi RB, Schettino GP, LorenziFilho G, Kairalla RA, Deheinzelin D, Munoz C, Oliveira R, et al: Effect of a protective-ventilation strategy on mortality in the acute respiratory distress syndrome. N Engl J Med 1998, 338(6):347-354.

6. Ranieri VM, Suter PM, Tortorella C, De Tullio R, Dayer JM, Brienza A, Bruno F, Slutsky AS: Effect of mechanical ventilation on inflammatory mediators in patients with acute respiratory distress syndrome: a randomized controlled trial. JAMA 1999, 282(1):54-61.

7. ARDSNet: Ventilation with lower tidal volumes as compared with traditional tidal volumes for acute lung injury and the acute respiratory distress syndrome. The Acute Respiratory Distress Syndrome Network. N Engl J Med 2000, 342(18):1301-1308.

8. Parsons PE, Eisner MD, Thompson BT, Matthay MA, Ancukiewicz M, Bernard GR, Wheeler AP: Lower tidal volume ventilation and plasma cytokine markers of inflammation in patients with acute lung injury. Crit Care Med 2005, 33(1):1-6, discussion 230-232.

9. Sundar S, Novack V, Jervis K, Patrick Bender S, Lerner A, Panzica P, Mahmood F, Malhotra A, Talmor D: Influence of Low Tidal Volume Ventilation on Time to Extubation in Cardiac Surgical Patients. Anesthesiology 2011.

10. De Conno E, Steurer MP, Wittlinger M, Zalunardo MP, Weder W, Schneiter D, Schimmer RC, Klaghofer R, Neff TA, Schmid ER, et al: Anesthetic-induced improvement of the inflammatory response to onelung ventilation. Anesthesiology 2009, 110(6):1316-1326.

11. Licker M, Diaper J, Villiger Y, Spiliopoulos A, Licker V, Robert J, Tschopp JM: Impact of intraoperative lung-protective interventions in patients undergoing lung cancer surgery. Crit Care 2009, 13(2):R41.

12. Wolthuis EK, Choi G, Dessing MC, Bresser P, Lutter R, Dzoljic M, van der Poll T, Vroom MB, Hollmann M, Schultz MJ: Mechanical ventilation with lower tidal volumes and positive end-expiratory pressure prevents pulmonary inflammation in patients without preexisting lung injury. Anesthesiology 2008, 108(1):46-54

13. Michelet P, D'Journo XB, Roch A, Doddoli C, Marin V, Papazian L, Decamps I, Bregeon F, Thomas P, Auffray JP: Protective ventilation 
influences systemic inflammation after esophagectomy: a randomized controlled study. Anesthesiology 2006, 105(5):911-919.

14. Choi G, Wolthuis EK, Bresser P, Levi M, van der Poll T, Dzoljic M, Vroom MB, Schultz MJ: Mechanical ventilation with lower tidal volumes and positive end-expiratory pressure prevents alveolar coagulation in patients without lung injury. Anesthesiology 2006, 105(4):689-695.

15. Fernandez-Perez ER, Keegan MT, Brown DR, Hubmayr RD, Gajic O: Intraoperative tidal volume as a risk factor for respiratory failure after pneumonectomy. Anesthesiology 2006, 105(1):14-18.

16. Wrigge H, Uhlig U, Zinserling J, Behrends-Callsen E, Ottersbach G, Fischer M, Uhlig S, Putensen C: The effects of different ventilatory settings on pulmonary and systemic inflammatory responses during major surgery. Anesth Analg 2004, 98(3):775-781, table of contents.

17. Wrigge H, Zinserling J, Stuber F, von Spiegel T, Hering R, Wetegrove $S$, Hoeft A, Putensen C: Effects of mechanical ventilation on release of cytokines into systemic circulation in patients with normal pulmonary function. Anesthesiology 2000, 93(6):1413-1417.

18. Schultz MJ, Haitsma JJ, Slutsky AS, Gajic O: What tidal volumes should be used in patients without acute lung injury? Anesthesiology 2007, 106(6):1226-1231.

19. Beck-Schimmer B, Schimmer RC: Perioperative tidal volume and intraoperative open lung strategy in healthy lungs: where are we going? Best Pract Res Clin Anaesthesiol 2010, 24(2):199-210.

20. Putensen $C$, Wrigge H: Tidal volumes in patients with normal lungs: one for all or the less, the better? Anesthesiology 2007, 106(6):1085-1087.

21. Licker M, Diaper J, Ellenberger C: Perioperative protective ventilatory strategies in patients without acute lung injuries. Anesthesiology 2008, 108(2):335-336, author reply 336-337.

22. Slinger P: Perioperative lung injury. Best Pract Res Clin Anaesthesiol 2008, 22(1):177-191

23. Levitt JE, Matthay MA: The utility of clinical predictors of acute lung injury: towards prevention and earlier recognition. Expert Rev Respir Med 2010, 4(6):785-797.

24. Licker $M$, Fauconnet $P$, Villiger $Y$, Tschopp JM: Acute lung injury and outcomes after thoracic surgery. Curr Opin Anaesthesiol 2009, 22(1):61-67.

25. Wolthuis EK, Korevaar JC, Spronk P, Kuiper MA, Dzoljic M, Vroom MB, Schultz MJ: Feedback and education improve physician compliance in use of lung-protective mechanical ventilation. Intensive Care Med 2005, 31(4):540-546.

26. Kalhan R, Mikkelsen M, Dedhiya P, Christie J, Gaughan C, Lanken PN, Finkel B, Gallop R, Fuchs BD: Underuse of lung protective ventilation: analysis of potential factors to explain physician behavior. Crit Care Med 2006, 34(2):300-306.

27. Wongsurakiat $P$, Pierson $D J$, Rubenfeld GD: Changing pattern of ventilator settings in patients without acute lung injury: changes over 11 years in a single institution. Chest 2004, 126(4):1281-1291.

28. Esteban A, Anzueto A, Frutos F, Alia I, Brochard L, Stewart TE, Benito S, Epstein SK, Apezteguia C, Nightingale P, et al: Characteristics and outcomes in adult patients receiving mechanical ventilation: a 28-day international study. JAMA 2002, 287(3):345-355.

29. Blum JM, Maile M, Park PK, Morris M, Jewell E, Dechert R, Rosenberg AL: A Description of Intraoperative Ventilator Management in Patients with Acute Lung Injury and the Use of Lung Protective Ventilation Strategies. Anesthesiology 2011.

30. Gajic O, Dara SI, Mendez IL, Adesanya AO, Festic E, Caples SM, Rana R, St Sauver JL, Lymp JF, Afessa B, et al: Ventilator-associated lung injury in patients without acute lung injury at the onset of mechanical ventilation. Crit Care Med 2004, 32(9):1817-1824.

31. Leung JM, Dzankic S: Relative importance of preoperative health status versus intraoperative factors in predicting postoperative adverse outcomes in geriatric surgical patients. J Am Geriatr Soc 2001, 49(8):1080-1085.

32. Pearse RM, Harrison DA, James P, Watson D, Hinds C, Rhodes A Grounds RM, Bennett ED: Identification and characterisation of the highrisk surgical population in the United Kingdom. Crit Care 2006, 10(3):R81.

33. Monk TG, Saini V, Weldon BC, Sigl JC: Anesthetic management and oneyear mortality after noncardiac surgery. Anesth Analg 2005, 100(1):4-10.

34. Bijker JB, van Klei WA, Vergouwe Y, Eleveld DJ, van Wolfswinkel L, Moons KG, Kalkman CJ: Intraoperative hypotension and 1-year mortality after noncardiac surgery. Anesthesiology 2009, 111(6):1217-1226.
35. Soni N: British Consensus Guidelines on Intravenous Fluid Therapy for Adult Surgical Patients (GIFTASUP): Cassandra's view. Anaesthesia 2009, 64(3):235-238

\section{Pre-publication history}

The pre-publication history for this paper can be accessed here: http://www.biomedcentral.com/1471-2253/11/22/prepub

doi:10.1186/1471-2253-11-22

Cite this article as: Fernandez-Bustamante et al.: Intraoperative ventilation: incidence and risk factors for receiving large tidal volumes during general anesthesia. BMC Anesthesiology 2011 11:22.

\section{Submit your next manuscript to BioMed Central and take full advantage of:}

- Convenient online submission

- Thorough peer review

- No space constraints or color figure charges

- Immediate publication on acceptance

- Inclusion in PubMed, CAS, Scopus and Google Scholar

- Research which is freely available for redistribution

Submit your manuscript at www.biomedcentral.com/submit
C Biomed Central 